\title{
"MORA SE KONKORDATU JOŠ I DANAS PRIPOZNATI PRAVNA SNAGA, JER ON IZMEDJU VALJANO PROGLAŠENIH ZAKONA NE MOŽE IZNIMKU ČINITI"
}

Izv. prof. dr. sc. Mirela Krešić*

UDK: 347.65.01(497.5)(091)

348.711:347.65(497.5)"1855"

DOI: $10.3935 /$ zpfz.71.2.02

Izvorni znanstveni rad

Primljeno: travanj 2021.

Nakon ukidanja neoapsolutizma i povratka ustavnosti raspravljalo se o valjanosti austrijskih propisa uvedenih putem patenata, pa tako i o valjanosti Konkordata. Stajališta o tome nerijetko su bila oprečna te se o tom pitanju raspravljalo ne samo s pravnog stajališta već $i$ kao o važnom nacionalno-političkom te crkvenom pitanju. Na temelju spisa iz fonda Stola sedmorice Hrvatskog državnog arhiva u povodu tužbe o nasljednom pravu nakon smrti biskupa Strossmayera u radu se rekonstruira pravni okvir uređenja oporučnog nasljeđivanja iza prelata te se analiziraju presude Sudbenog stola u Osijeku, Banskog stola te Stola sedmorice, odnosno argumentacija tih sudova kojom je pola stoljeća nakon sklapanja Konkordata (ponovno) potvrđena njegova valjanost.

Ključne riječi: Konkordat iz 1855., Opći građanski zakonik, Hrvatska i Slavonija, Josip Juraj Strossmayer, oporuka

* Dr. sc. Mirela Krešić, izvanredna profesorica Pravnog fakulteta Sveučilišta u Zagrebu, Trg Republike Hrvatske 14, 10000 Zagreb; mirela.kresic@pravo.hr;

ORCID ID: orcid.org/0000-0001-7065-7129 


\section{UVOD**}

Početkom neoapsolutizma uvođenjem niza austrijskih zakona znatno je izmijenjen pravni sustav Kraljevine Hrvatske i Slavonije. ${ }^{1}$ Te su promjene utjecale na dotadašnji sustav nasljeđivanja jer je Općim građanskim zakonikom (dalje u tekstu: OGZ) uspostavljeno jedinstveno nasljednopravno uređenje s obzirom na osobe i s obzirom na stvari. ${ }^{2}$ Jedinstvenost nasljednopravnog uređenja s obzirom na osobe bila je posljedica pravne jednakosti svih građana te je svatko, neovisno o spolu te staleškoj pripadnosti, dobio mogućnost nasljeđivati i biti nasljeđivan. ${ }^{3} \mathrm{~S}$ obzirom na stvari ta je jedinstvenost značila uklanjanje razlika u nasljeđivanju pokretnina i nekretnina, odnosno naslijeđene i stečene imovine.

Iznimku od općih pravila i načela predstavljao je \$761. kojim je predviđena mogućnost da se propisi o zakonskom nasljeđivanju ne primjenjuju za nasljeđivanje svećenstva (“osoba duhovnih”), dok je Patentom o uvođenju OGZ-a na hrvatsko-slavonsko područje bila propisana primjena prije važećih propisa u pogledu oporučne slobode prelata, tj. visokih dostojanstvenika Katoličke Crkve, u pogledu raspolaganja stečenom imovinom. ${ }^{4} \mathrm{Uz}$ OGZ primjenjivao se i Izvanparbeni postupnik (dalje u tekstu: Izv. p.p.), kojim je bilo propisano kako svjetovne pravne poslove svećenstva, u koje pripadaju i ostavinski predmeti, rješavaju redovni sudovi. ${ }^{5}$ Izv. p.p. u međuratnom je razdoblju zamijenjen jugo-

** Rad je rezultat istraživanja provedenog u sklopu projekta "Europski korijeni moderne Hrvatske: transfer ideja na političkom i kulturnom polju u 18. i 19. stoljeću" (IP-2018-01-2539), koji financira Hrvatska zaklada za znanost.

1 Dalje u tekstu umjesto naziva Hrvatska i Slavonija i odgovarajućih izvedenica koristi se naziv Hrvatska, osim kad je nužno istaknuti kako je upravo riječ o "Hrvatskoj i Slavoniji”, odnosno o "hrvatsko-slavonskom području".

2 Cesarski patent od 29. studena 1852. kriepostan za kraljevine Ugarsku, Hrvatsku i Slavoniju, vojvodinu srbsku i tamiški banat, kojim se za ove krunovine uvodi sa više stegah i s potanjim ustanovami obći gradjanski zakonik od 1. lipnja 1811., i u kriepost stavlja počamši od 1. svibnja 1853. i tekst OGZ-a u: Rušnov, A.; Posilović, S., Tumač obćemu austrijskom gradjanskom zakoniku, knjiga I. i knjiga II., Tisak i naklada knjižare L. Hartmana (Stj. Kugli), Zagreb, [1910].

3 Iznimku su predstavljali članovi tzv. duhovničkih redova koji su položili zavjet siromaštva te nisu mogli stjecati imovinu inter vivos i mortis causa (\$538. OGZ-a); usp. Rješenje kr. Banskog stola od 6. srpnja 1893., br. 12239, Mjesečnik Pravničkog društva, god. XX, br. 11, 1894., str. $502-503$.

4 Čl. VII. toč. 3. b) Patenta, Rušnov; Posilović, op. cit. u bilj. 2, knjiga I., str. 22.

5 Zakon o sudbenom postupku u pravnim poslovima neparbenim iliti izvan parnica (poznatiji kao Izvanparbeni postupnik) od 9. kolovoza 1854., Hrvatski zakoni III, Knjižara Lav. Hartmana (Kugli i Deutsch), Zagreb, 1900., str. 1 - 160. 
slavenskim Zakonom o sudskom vanparničnom postupku (1934.). ${ }^{6}$ Uz navedene zakone relevantna je bila primjena i niza podzakonskih propisa koje je, posebno u razdoblju do 1918. godine, donijela Zemaljska vlada. ${ }^{7}$

Za svećenike Katoličke Crkve je, osim toga, bila važna i primjena Konkordata koji je 1855. godine car Franjo Josip sklopio s papom Pijom IX. ${ }^{8}$ Nakon ukidanja neoapsolutizma i povratka ustavnosti 1860. raspravljalo se o valjanosti propisa uvedenih putem patenata, pa tako i pitanje valjanosti Konkordata. Stajališta o tome nerijetko su bila oprečna te se o tom pitanju raspravljalo ne samo s pravnog stajališta već i kao o važnom nacionalno-političkom te crkvenom pitanju. Među autorima koji su sudjelovali u ovim raspravama prevladalo je mišljenje kako je povratkom ustavnosti Konkordat i nadalje ostao na snazi na području Hrvatske i Slavonije te su slijedom prihvaćenog stajališta postupala hrvatska upravna i sudska tijela u razdoblju Austro-Ugarske Monarhije (dalje u tekstu: Monarhija), ali i nakon 1918. godine i stvaranja Kraljevine SHS/Jugoslavije (dalje u tekstu: Kraljevina).

Jedan od najglasnijih zagovaratelja Konkordata bio je đakovačko-srijemski biskup Josip Juraj Strossmayer. No, upravo je njegovo oporučno raspolaganje ponovno nametnulo raspravu o valjanosti Konkordata. Pred hrvatskim sudovima u ovom se konkretnom slučaju o valjanosti Konkordata raspravljalo u kontekstu njime zajamčene slobode oporučnog raspolaganja prelata. ${ }^{9}$ Dok su biskupovi oporučni nasljednici tvrdili kako je oporuka valjana jer je §XXI. Konkordata

6 Zakon o sudskom vanparničnom postupku, Službene novine Kraljevine Jugoslavije od 1. augusta 1934., br. 175 - XLV.

7 Važne su bile dvije vladine naredbe iz 1918. u kojima su, zbog različitih i brojnih izvora od kojih su neki datirali još iz 17. stoljeća i bili pisani latinskim jezikom, za potrebe prakse izložena načela postupanja nakon smrti prelata. Naredba hrv. slav. dalm. zemaljske vlade, odjela za bogoštovlje i nastavu te odjela za pravosudje, od 21. listopada 1918. br. 20.673, o postupku povodom smrti katoličkih biskupa (zagrebačkog nadbiskupa metropolite i sufraganih mu biskupa), uživaoca nadarbina kraljeva imenovanja; Naredba hrv. slav. dalm. zemaljske vlade, odjela za bogoštovlje i nastavu, od 21. listopada 1918., broj 30, 779, o upravi, nadzoru i predaji nadarbine zagrebačkog nadbiskupa - metropolite, kao što i nadarbine sufraganih mu biskupa kraljeva imenovanja, Zbornik zakona i naredaba valjanih za Hrvatsku i Slavoniju, god. 1918., kom. XV, br. 97 i br. 98.

8 Cesarski patent od 5. studenog 1855., kriepostan za svekoliku cesarevinu kojim se proglašuje ugovor (konkordat), Pokrajinski list uredovnih spisah za Dalmaciu. Dio pervi, komad XXXIII. Razdan i razposlan na 6. prosinca 1855., br. 209, str. 952 - 980.

9 Načelo slobode oporučnog raspolaganja načelo je zajamčeno Konkordatom, ali ujedno i jedno od načela nasljednopravnog uređenja uvedenog OGZ-om i kao takvo odraz načela dispozitivnosti, jednog od temeljnih načela građanskog prava. 
zajamčena neograničena sloboda oporučnog raspolaganja, osporavatelji oporuke tvrdili su kako Konkordat više nije na snazi. Slijedom toga primjenjuju se prije važeći propis, tzv. Kolonićeva konvencija (dalje u tekstu: Konvencija) na temelju koje prelat za oporučno raspolaganje cijelom svojom imovinom mora tražiti odobrenje vladara. Supsidijarno su osporavatelji oporuke tvrdili da ako Konkordat ipak jest na snazi, onda §XXI. kojim se upućuje na primjenu juxta sacros canones podrazumijeva upravo primjenu Konvencije i obvezu prelata tražiti odobrenje vladara za oporučno raspolaganje cijelom svojom imovinom.

$\mathrm{Na}$ temelju spisa iz fonda Stola sedmorice Hrvatskog državnog arhiva u povodu tužbe o nasljednom pravu nakon smrti biskupa Strossmayera u radu se rekonstruira pravni okvir uređenja oporučnog nasljeđivanja iza prelata te se analiziraju presude Sudbenog stola u Osijeku, Banskog stola te Stola sedmorice, odnosno argumentacija tih sudova kojom je pola stoljeća nakon sklapanja Konkordata (ponovno) potvrđena njegova valjanost.

\section{TUŽBA O NASLJEDNOM PRAVU U POVODU OPORUKE BISKUPA JOSIPA JURJA STROSSMAYERA}

Na zasjedanju đakovačkog Stolnog kaptola 9. travnja 1905. godine pročitana je oporuka dan prije preminulog biskupa Josipa Jurja Strossmayera. Biskup je oporukom za svoje nasljednike imenovao Dječačko sjemenište u Osijeku, Stolnu crkvu u Đakovu te Zakladu za osnivanje dva kanonička mjesta pri Stolnom kaptolu. ${ }^{10}$ Isti je dan Banski stol obavijestio Odjel za bogoštovlje i nastavu Zemaljske vlade kako je za provođenje ostavinske rasprave delegiran Kraljevski sudbeni stol u Osijeku. ${ }^{11}$ Tijekom ostavinske rasprave nasljedno su se očitovali na temelju oporuke nasljednici navedeni u oporuci koje je tijekom postupka

10 Tekst oporuke vidi u: Sršan, S. (prir.), Ostavština đakovačkog i srijemskog biskupa Josipa Jurja Strossmayera 1905. godine: zapisnici ostavinskog povjerenstva i spisi ostavinske rasprave, Hrvatska akademija znanosti i umjetnosti, Zavod za znanstveni i umjetnički rad: Državni arhiv Đakovo; Đakovačka i srijemska biskupija, Zagreb - Osijek, 2006., str. XIV - XVI.

11 Naredba Kr. banskog stola od 9. travnja 1905., br. 8644. Prethodne radnje koje su uključivale izradu smrtovnice, pečaćenje privatnih prostorija i predaju pronađene gotovine i zlatnine Kr. kotarskom sudu u Đakovu poduzeo je javni bilježnik dr. Vladimir Prebeg. Njegovu molbu da mu se odobri izrada popisa ostavine (našastara) i provedba ostavinske rasprave odbio je Kr. sudbeni stol u Osijeku, a tu je odluku nakon žalbe (utoka) dr. Prebega potvrdio i Banski stol. Rješidba Kr. banskog stola od 10. svibnja 1905., br. 10517; Hrvatski državni arhiv, fond 394, Stol sedmorice (1862 - 1945), serija ostavina, kutija 3., Os-IV-421/1905. (dalje u tekstu svi dokumenti iz ovog arhivskog izvora citirat će se: HDA, Stol sedmorice, kut. 3.). 
zastupalo Kraljevsko državno nadodvjetništvo u Zagrebu. Nasljedno očitovanje na temelju zakona izjavila je rodbina biskupa Strossmayera te Kraljevski državni financijalni erar, zastupan po Kraljevskom ravnateljstvu erarnih pravnih poslova, potražujući 1/3 ostavine i pozivajući se na Konvenciju. ${ }^{12}$ S obzirom na oprečna nasljedna očitovanja, odlukom Stola sedmorice pozvani su Financijalni erar i srodnici ostavitelja da u roku od 60 dana podnesu tužbu protiv oporučnih nasljednika i ospore valjanost oporuke. ${ }^{13}$

Financijalni erar (dalje u tekstu: tužitelj) pravodobno je podnio tužbu osporavajući oporuku te navodeći kako biskup nije imao odobrenje vladara da oporučno raspolaže cijelom svojom imovinom kako to zahtijeva Konvencija te da slijedom toga tužitelj kao zakonski nasljednik ima pravo na 1/3 ostavine. Istodobno su oporučni nasljednici tvrdili kako je oporuka valjana jer je §XXI. Konkordata zajamčena neograničena sloboda oporučnog raspolaganja. Tužitelj je zatim izjavio kako Konkordat više nije na snazi, odnosno ako i jest na snazi, ipak nije ukinuo Konvenciju. Ne uvažavajući navode tužitelja o stavljanju izvan snage Konkordata te važenju pravila Konvencije o oporučnom raspolaganju

12 Nasljedno očitovanje predaja je prijave nasljedstva u kojoj je bilo potrebno izričito navesti prihvaća li se ili ne prihvaća nasljedstvo. Ako se nasljedstvo prihvaćalo, bilo je potrebno navesti i po kojoj osnovi - na temelju oporuke, zakona ili nasljednog ugovora - te prihvaća li se nasljedstvo bezuvjetno ili uvjetno. Također, nasljedna prijava morala je biti vlastoručno potpisana i predana u određenom roku. Ako je bilo više nasljednika, svaki od njih podnosio je vlastitu prijavu nasljedstva ( $\$ 115$. - 117., 122. Izv. p.p.).

13 Rješidba Kr. hrv. slav. dalm. Stola sedmorice od 5. svibnja 1906. br. 1102., HDA, Stol sedmorice, kut. 3. Ako je predano više nasljednih prijava koje su međusobno proturječne, sud je morao primiti sve prijave i zatim stranke uputiti na parnicu ocjenjujući koja se stranka imala smatrati tužiteljem odnosno tuženikom kao i rok u kojem se je trebala podići tužba, i to tužba o nasljednom pravu. S obzirom na moguće kolizije nasljednih prijava, zakonom je bilo propisano kako je u slučaju kolizije između nasljedne prijave temeljene na nasljednom ugovoru s jedne strane te nasljedne prijave oporučnog ili zakonskog nasljednika, položaj tužitelja imao je potencijalni oporučni ili zakonski nasljednik, a ako je postojala kolizija između prijave oporučnog i zakonskog nasljednika, položaj tužitelja dobivao je zakonski nasljednik. U slučaju kolizije između nasljednih prijava nasljednika iste pravne osnove nasljeđivanja, položaj tužitelja davao se onome tko je, kako bi dokazao svoje nasljedno pravo, morao oboriti jaču osnovu nasljeđivanja ili pravni naslov svojeg protivnika. Na temelju ove odredbe na parnicu se kao tužitelj uvijek upućivao onaj nasljednik koji je svoju nasljednu prijavu zasnivao na slabijem pravnom naslovu, što je u pravilu bio potencijalni zakonski nasljednik, ako su nasljedni ugovor i oporuka zadovoljavali sve propisane formalnosti. Tužba o nasljednom pravu imala je obilježje prejudicijelne tužbe kojom se tražilo utvrđenje, tj. priznanje nasljednog prava (\$§125. - 127. Izv. p.p.). 
prelata, Sudbeni stol u Osijeku kao prvostupanjski sud odbio je tužbeni zahtjev, potvrdio valjanost oporuke te dosudio tuženicima naknadu parničnih troškova u iznosu od 1681 kruna i 50 forinti. $^{14}$

$\mathrm{Na}$ odluku osječkog suda tužitelj je zatim uložio ništavnu žalbu te priziv Banskom stolu u Zagrebu ${ }^{15}$, koji je nakon provedenog postupka odbacio ("zabacio") ništavnu žalbu, odbio ("odputio") priziv u glavnoj stvari ("valjanost oporuke") i u tom dijelu potvrdio odluku nižeg suda, ali je uvažio priziv u pogledu parničnih troškova te je taj dio presude preinačio i parnične troškove prebio između stranaka. ${ }^{16}$

Tužitelj je na odluku Banskog stola uložio izvanredni previd Stolu sedmorice. ${ }^{17}$ Previd, ali u pogledu parničnih troškova, uložili su i tuženici. Stol sedmorice tužiteljev je izvanredni previd odbio kao nedopustiv, jednako kao i previd tuženika, te u cijelosti potvrdio odluku Banskog stola. ${ }^{18}$ Tom presudom Stola sedmorice dovršen je ostavinski postupak pokrenut u povodu osporavanja oporuke biskupa Strossmayera.

\section{KOLONIĆEVA KONVENCIJA O OPORUČNOM RASPOLAGANJU PRELATA}

Prije uvođenja OGZ-a nasljeđivanje svećenstva karakterizirala je različitost propisa ovisno o tome je li riječ o nasljeđivanju višeg ili nižeg svećenstva. U više svećenstvo ili prelate kao dostojanstvenike Katoličke Crkve koji su imali vlastitu jurisdikciju ubrajali su se (nad)biskupi, opati te prepoziti (prepošti) na čelu kaptola ili samostana nekog od katoličkih redova i koji su imali plemićko dobro stečeno kraljevskom darovnicom. ${ }^{19}$ Prije 1848. godine prelati su imali položaj

14 Osuda Kr. sudbenog stola u Osijeku od 2. ožujka 1907., br. 2101, HDA, Stol sedmorice, kut. 3.

15 Ništavna žalba i priziv pravni su lijekovi koji su se mogli izjaviti protiv presuda nižih sudova prema §339. odnosno §308. Privremenog građanskog postupnika (dalje u tekstu: G.p.p.).

16 Rješidba Kr. banskog stola od 1. svibnja 1907., br. 8024, HDA, Stol sedmorice, kut. 3.

17 Izvanredni previd pravni je lijek koji se izjavljivao prema §335. G.p.p.

18 Rješidba Kr. hrv. slav. dalm. stola sedmorice od 12. rujna 1907., br. 3030, HDA, Stol sedmorice, kut. 3.

19 Kraljevska darovnica (donatio regia) jest privilegij/isprava kojom se nekome (pojedincu/obitelji/rodu) zbog javnih zasluga dodjeljivalo vlasništvo (ius perennale seu perpetuum) plemićkog dobra. Darovnica je sadržavala osnovu darovanja, pravni naslov na temelju kojeg je vladar raspolagao predmetom darovanja i opis međe predmeta darovanja te potvrdu o uvođenju u posjed, s time da je uvođenje moralo biti izvr- 
staleža (status et ordines regni) s pravom na osobno sudjelovanje (sjedište) i glas u Hrvatsko-slavonskom saboru. ${ }^{20}$ Niže svećenstvo činili su kanonici, župnici, upravitelji, kapelani i ostali pripadnici klera.

Pravila nasljeđivanja iza prelata bila su sadržana u Zak. čl. 1715:XVI. Ugarskog sabora kojim je bila potvrđena Konvencija. ${ }^{21}$ Konvencija je bila rezultat višestoljetnih prepiranja crkvenih i svjetovnih vlasti oko prava raspolaganja mortis causa crkvenih osoba, sklopljena 1702. godine između Dvorske komore i ugarskog svećenstva na čelu s Leopoldom Kolonićem, kardinalom i ugarskim primasom te ostrogonskim nadbiskupom. ${ }^{22}$ Rješenjima sadržanim u Konvenciji svećenstvo ipak nije bilo zadovoljno te je 1715. godine na saborskom zasjedanju izabrano povjerenstvo koje je trebalo ponovno urediti pitanje raspolaganja mortis causa, dok je za prijelazno razdoblje bio usvojen spomenuti Zak. čl. XVI. Kako povjerenstvo nije ispunilo zadatak zbog kojeg je imenovano, Konvencija je bila na snazi u trenutku uvođenja OGZ-a. ${ }^{23}$

Konvencijom je uređeno oporučno te neoporučno odnosno zakonsko nasljedno pravo prelata i postupak nakon njihove smrti. Prema Konvenciji su se iz ostavine umrlog prelata najprije podmirivali troškovi pogreba, plaće sluga i potraživanja ostaviteljevih vjerovnika. ${ }^{24}$ Nakon toga su se morali izdvojiti knjige i rukopisi u korist kaptola ili ostaviteljeve nadarbine s ciljem povećanja

šeno bez prigovora trećih osoba. Osnovu darovanja činile su zasluge koje je darovani ostvario za krunu, kralja i kraljevstvo. Prelatska (plemićka) dobra najvećim dijelom stečena su upravo kraljevskom darovnicom, a zbog izjednačenja prelata sa svjetovnim plemstvom bili su oslobođeni od različitih javnih tereta (npr. poreza) dok su istodobno imali pravo ubirati različite prihode od podanika koji su živjeli na tim dobrima. Lanović, M., Privatno pravo Tripartita, Tipografija D.D., Zagreb, 1929., str. 226.

20 Beuc, I., Povijest institucija državne vlasti Kraljevine Hrvatske, Slavonije i Dalmacije, Pravni fakultet - Centar za stručno usavršavanje i suradnju s udruženim radom, Zagreb, 1985., str. $185-187$.

${ }^{21}$ Za tekst Konvencije vidi Nánásy, B., Testamentom a’ magyar országi törvények szerént, Trattner Mátjás betújvel, Pesthen, 1798., str. 52 - 65.

22 Sedlák, P., Leopold Kollonić (1631. - 1707.) - kardinal hrvatskog podrijetla i njegova crkvena i politička djelatnost (300. obljetnica smrti primasa Leopolda Kollonića), Croatica Christiana periodica, vol. 31, br. 60, 2007., str. 85 - 99.

Lanović, op. cit. u bilj. 19, str. 304.

24 Prelatovu imovinu čine naslijeđena imovina (bona patrimonialia), privređena imovina (industrialia vel quasi patrimonialia) i ušteđena imovina (parsimonialia) te je $s$ njome mogao u načelu slobodno raspolagati, za razliku od crkvenih ili nadarbinskih dobara koja mu pripadaju kao službeniku Crkve i čiji je isključivi uživatelj. Belaj, F., Katoličko crkveno pravo, Tisak i naklada knjižare L. Hartmana (Stj. Kugli), Zagreb, 1901., str. $128-129$. 
knjižnice, zatim predmeti koji su ostajali crkvi poput svećeničkih odijela, svetih posuda i crkvenih ukrasa (veluti res Deo dedicatae) i konačno su se izdvajali predmeti tzv. fundus instructus koji su pripadali njegovu nasljedniku na položaju (§3.). Preostala prelatova imovina zatim se dijelila na tri jednaka dijela. Trećina ostavine upotrebljavala se za crkvene svrhe te su se njome podizala nova ili povećavala postojeća sjemeništa, poboljšavale su se crkve ili popravljale župe. Trećina ostavine pripadala je Ugarskoj kraljevskoj komori25 ${ }^{25}$ dok je preostalom trećinom prelat mogao oporučno raspolagati (\$4.).

Trećina predviđena za oporučno raspolaganje predstavljala je zapravo ograničenje slobode raspolaganja mortis causa. Naime, neograničena sloboda raspolaganja koja je pripadala prelatima kao plemstvu počela se ograničavati tijekom 12. stoljeća prisvajanjem pokretne imovine svećenstva (ius spollii ili exuviarum) od strane svjetovnih vlasti. ${ }^{26}$ Prvo značajnije uređenje oporučnog, ali i neoporučnog raspolaganja prelata predstavljala je diploma kralja Ferdinanda iz 1625. godine na temelju koje su prelati mogli oporučno raspolagati samo s polovicom svoje pokretne imovine, dok se druga polovica morala upotrijebiti za crkvene svrhe. ${ }^{27}$ Daljnje smanjenje imovine kojom su mogli oporučno raspolagati - s polovice na trećinu - uslijedilo je upravo Konvencijom. Ako prelat nije oporučno raspolagao trećinom slobodnom za raspolaganje, nasljeđivali su je srodnici i to do desetog koljena, a ako nije bilo srodnika, polovica te trećine išla je Komori, a polovica za crkvene svrhe. ${ }^{28}$ Ako je prelat raspolagao s više od dopuštene jedne trećine, oporuka je bila nevaljana, ali samo u onom dijelu koji je prelazio dopuštenu

25 Odredba o trećini koja je bila namijenjena Ugarskoj kraljevskoj komori posljedica je prilika u kojima se stoljećima nalazilo Ugarsko-Hrvatsko Kraljevstvo s obzirom na stalno prisutnu tursku opasnost. Ovako prikupljeni prihodi bili su predviđeni za uzdržavanje posada i utvrda na graničnim područjima. Ujedno su prelati i na temelju saborskih odluka još od sredine 15. stoljeća bili obvezni pridonositi kraljevskoj vojsci s određenim brojem vojnika te ih i uzdržavati, pa i sami ići u rat ako je to bilo potrebno. Neke od najvažnijih osoba hrvatske povijesti iz vremena vojnih sukoba s Osmanlijskim Carstvom bili su upravo biskupi - vojskovođe kao npr. vranski prior, vesprimski biskup i ban Petar Berislavić.

26 Gross, K., Udžbenik crkvenog prava Katoličke crkve, Naklada školskih knjiga i tiskanica kr. Banske uprave Savske banovine, Zagreb, 1930., str. 402.

$27 \mathrm{U}$ diplomi se navode samo pokretnine. Nekretnine su u pravilu bile avitičke te su prema zakonu, tj. Tripartitu pripadale rodbini. Ako su nekretnine ipak bile stečene, mogao je prelat s njima slobodno raspolagati jer se jus spolii odnosio samo na pokretnine. Belaj, op. cit. u bilj. 24, str. 133; Galić, I., O oporučnoj slobodi i zakonskom nasljedovanju iza katoličkih duhovnih osoba, Mjesečnik Pravničkog društva u Zagrebu, god. XXXVI, br. 11, 1910., str. 982.

28 Belaj, op. cit. u bilj. 24, str. 133; Lanović, op. cit. u bilj. 14, str. 304; Galić, op. cit. u bilj. 27, str. 984 . 
trećinu. Međutim, neovisno o ovom ograničenju, ako je prelat htio raspolagati cijelom svojom ostavinom, morao je zatražiti kraljevsko odobrenje, koje se dobivalo uz plaćanje određenog iznosa u kraljevsku blagajnu i obvezu da se nadarbini odnosno nasljedniku na položaju ostavi netaknuti fundus instructus. ${ }^{29}$

Unatoč izjednačenju prelata s plemstvom ostavinski postupak u ovom razdoblju nisu provodili sudovi već upravna tijela vlasti. Konvencijom je bila propisana obveza pečaćenja ostavine - pokretnine i isprave - od strane dvaju predstavnika kaptola i komorskog činovnika. Ako u mjestu smrti nije bilo predstavnika komore, predstavnici kaptola mogli su samostalno zapečatiti imovinu uz obavijest činovniku i obrnuto, činovnik je samostalno pečatio ako nije bilo predstavnika kaptola uz obavijest o smrti. Nakon pečaćenja ostavine sastavljao se njezin popis u tri primjerka te se provodila procjena ostavine. Jedan primjerak popisa se s oporukom morao predati pokojnikovu ordinariju, drugi primjerak metropolitu, a treći primjerak komorski je činovnik dostavljao komori. Ostaviteljeve nekretnine (naslijeđene ili stečene, u pogledu kojih prelat nije imao kraljevo odobrenje za oporučno raspolaganje) popisivao je i procjenjivao samostalno komorski činovnik. Izvršenje oporuke provodile su osobe koje su imenovali ordinarij, metropolit te kraljevska komora (\$5.). Za Marije Terezije propisano je kako su pečaćenje i popis ostavine obavljali izaslanici komore i kaptola uz sudjelovanje dvaju predstavnika županijskog magistrata kao testimonium legale. ${ }^{30}$ Naknadno je kraljevska dvorska komora propisala kako se komorski činovnik morao pobrinuti da kaptol i županija nakon smrti prelata izaberu svoje izaslanike, pri čemu je predstavnik županije i dalje djelovao kao testimonium legale. ${ }^{31}$

\section{IZNIMKE OPĆEG GRAĐANSKKOG ZAKONIKA}

Nasljednopravno uređenje OGZ-a dopuštalo je određene iznimke u pogledu svećenstva. Iznimku od općih pravila i načela predstavljao je spomenuti \$761. kojim je predviđena neprimjena pravila o zakonskom nasljeđivanju. Na snazi su tako i dalje ostala prijašnja pravila zakonskog nasljeđivanja uz dopunu sadržanu

29 Galić op. cit. u bilj. 27, str. $984-986$.

30 Intimatum de dato 8 - vae Julii 1773. Nro. 3145., u: Nánásy, op. cit. u bilj. 21, str. $65-67$.

31 Galić, I., O postupku nakon smrti katoličkih prelata, o preuzeću i upravi ispražnjenih prelatskih nadarbina, o diobi dohodaka nadarbine i godini prelatove smrti te o predaji nadarbine novo imenovanom prelatu, Mjesečnik Pravničkog društva u Zagrebu, knjiga I, god. XXXVIII, br. 1, 1912., str. 4. 
u Patentu o uvođenju OGZ-a na temelju koje je predviđena primjena pravila OGZ-a o zakonskom nasljeđivanju u pogledu onog dijela imovine koja bi prema prijašnjim pravilima pripadala rodbini. ${ }^{32}$ Riječ je, prema tome, o onom dijelu imovine, tj. trećini prelatove ostavine kojom nije oporučno raspolagao, a koja je prema Konvenciji pripadala rodbini, odnosno ako prelat nije imao rodbine, onda je polovica tog dijela pripadala fisku, a polovica crkvi. Promjene koje je uveo OGZ obuhvaćale su smanjenje kruga potencijalnih nasljednika te su sada nasljeđivali srodnici iz šest nasljednih redova (\$731.), a ako nije bilo srodnika, bila je riječ o ošasnoj imovini koja je pripadala državi (\$760.). ${ }^{33}$

U pogledu oporučnog nasljeđivanja Patentom o uvođenju OGZ-a propisana je primjena prije važećih propisa $u$ pogledu raspolaganja stečenom imovinom. ${ }^{34}$ Pritom se mislilo na Konvenciju i u njoj sadržano ograničenje na temelju kojeg su prelati mogli raspolagati mortis causa s trećinom stečene imovine.

Promjenu u dotadašnje postupanje unio je i Izv. p.p. na temelju kojeg se ostavinski postupak iza smrti prelata raspravljao pred redovnim građanskim sudovima. ${ }^{35}$ Ostavinski postupak ipak nije bio u potpunosti izjednačen s ostavinskim postupcima iza ostalih građana te su se i nadalje, u točno određenim slučajevima (\$\$57., 107.), primjenjivali prije važeći propisi. Prema Izv. p.p. nadležni sud je nakon smrti prelata bio obvezan provesti prethodne radnje, tj. sastaviti smrtovnicu, potražiti oporuku, zapečatiti ostavinu (\$§ 28. - 49.) te obavijestiti Zemaljsku vladu i kaptol (\$ 57.). Pritom se moralo voditi računa kako se u prelatovu posjedu nalazila i imovina koja je bila vlasništvo nadarbine te ju je bilo potrebno razlučiti od ostale prelatove imovine (\$107.). Ovaj pravni okvir bio je na snazi do sklapanja Konkordata 1855. godine.

32 Čl. VII. toč. 3. c) Patenta, Rušnov; Posilović, op. cit. u bilj. 2, knjiga I., str. 22.

33 Čl. VII. toč. 4. Patenta, Rušnov; Posilović, op. cit. u bilj. 2, knjiga I., str. 22. Ošasna ostavina koja se nalazila na području Hrvatske i Slavonije (civilnog i bivšeg krajiškog dijela) pripadala je zajedničkom ugarsko-hrvatskom eraru. Okružnica kralj. banskog stola od 31. svibnja 1876., br. 5677, glede pitanja komu pripadaju ošastne ostavštine. Okružnica kr. banskog stola od 29. studenoga 1882., br. 23530, kojom se okružnica kr. banskoga stola od 31. svibnja 1876., br. 5677 proteže i na područje bivše hrvatsko-slavonske krajine. Uredovna sbirka naredabah pravosudne struke, svezak I, Zagreb, 1885., br. 31; usporedi Rješenje kr. stola sedmorice od 24. lipnja 1896., br. 14718, Mjesečnik Pravničkog društva, XXII, 1896., str. 552.

34 Čl. VII. toč. 3. b) Patenta, Rušnov; Posilović, op. cit. u bilj. 2, knjiga I., str. 22.

35 Čl. III. Cesarskog patenta od 9. kolovoza 1854 krjepostan za svekolike krunovine, izim Krajine vojničke, Hrvatski zakoni III, Zagreb, 1900., str. 1 - 3. 


\section{KONKORDAT (I) NA HRVATSKO-SLAVONSKOM PODRUČJU}

Odnos Monarhije i Katoličke Crkve narušen je tijekom prosvijećenog apsolutizma i provođenja reformi kojima je bila zahvaćena i Crkva s ciljem ograničavanja njezine društvene uloge kao feudalne institucije te snaženju državnog nadzora nad njom. Pritom su se, sa stajališta Crkve, posebno tegobnima pokazale mjere Josipa II. kojima je Crkva uklonjena iz sustava školstva, ukinuti su brojni redovi te je smanjen broj samostana, ali i proglašena tolerancija prema drugim vjerskim zajednicama. ${ }^{36}$ Okolnosti djelovanja Crkve promijenile su se 1850. kada je Travanjskim uredbama ukinuta tzv. jozefinistička državna crkva. ${ }^{37}$ Ubrzo je zatim sklopljen Konkordat (1855.), kojim je Crkva ponovno ojačala i stekla široke ovlasti nad brojnim izvancrkvenim područjima uključujući školstvo te kojim je zajamčeno izuzimanje katolika od primjene bračnog prava OGZ-a. ${ }^{38}$ Papa je Konkordat proglasio bulom Deus humanae salutis auctor, dok je za područje Monarhije izdan i proglašen carskim patentom na način kako su se izdavali i proglašavali državni zakoni u vrijeme apsolutističke vladavine. Na taj je način Konkordat imao snagu i crkvenog i državnog zakona ${ }^{39}$, no odmah je stekao brojne protivnike i u austrijskom dijelu Monarhije i u Kraljevini Ugarskoj.

Povratak ustavnosti (1860.) osjetnije je problematizirao valjanost Konkordata i položaj konkordatske Katoličke Crkve. U austrijskom dijelu Monarhije prvi veći uspjeh usmjeren na njegovo ukidanje ostvaren je prilikom pregovora u Carevinskom vijeću o prihvaćanju Austro-ugarske nagodbe (1867.), kada su austrijsko-njemački liberali ishodili prihvaćanje pet temeljnih državnih zakona ustavne važnosti, a zatim i niza zakona kojima je npr. uređeno bračno pravo,

36 Gross, M., Počeci moderne Hrvatske, Globus, Zagreb, 1986., str. 325.

37 Za sadržaj Travanjskih uredbi vidi Hoško, F. E., Promaknuće Zagrebačke biskupije u nadbiskupiju omogućila je revolucionarna 1848. godina, Riječki teološki časopis, god. 26, br. 1, 2018., str. 153 - 154; usporedi Aliprantis, C., The afterlife of Enlightened Absolutism: commemoration of Maria Theresa and Joseph II and the politics of liberal reform in nineteenth-century imperial Austria, European Review of History, vol. 26, br. 2, 2019. str. $305-330$.

38 §X. Konkordata katolički brakovi bili su u nadležnosti crkvenih tijela te su slijedom toga bili doneseni Ženidbeni zakon za katolike (1856.) te Naputak za duhovne sudove glede stvari ženidbenih (1856.). Krešić, M., Much Ado about Nothing - Debates on the Type of Marriage in Yugoslavia between the Two World Wars, u: Löhnig M. (ur.), Kulturkampf um die Ehe, Reform das europäischen Eherechts nach dem Grossen Krieg, Mohr Siebeck, Tübingen, 2021., str. 199 - 202.

39 Lovrić, E., Vrijednost konkordata u Hrvatskoj prije i nakon sloma Austro-Ugarske, Mjesečnik Pravničkog društva, god. XLVIII, br. 4-5, 1921., str. 200; usporedi §XXXV. Konkordata. 
međuvjerski odnosi i školstvo protivno sadržaju Konkordata te uz protivljenje austrijske Katoličke Crkve. ${ }^{40}$ Proglašenje dogme o papinskoj nepogrešivosti na Prvom vatikanskom saboru 1870. godine potaknulo je konačno donošenje zakona kojim je 1874. Konkordat ukinut kao državni zakon za područje austrijskog dijela dvojne Monarhije (uključujući Istru i Dalmaciju). ${ }^{41}$

Ugarska Katolička Crkva i javnost otpočetka nisu prihvaćali Konkordat ponajprije zbog političkih razloga, smatrajući ga neustavnim i protumađarskim te instrumentom habsburškog apsolutizma i germanizacije. ${ }^{42}$ Stoga je povratkom ustavnosti i na temelju prijedloga Judex-kurijalne konferencije na Ugarskom saboru (1861.) prihvaćeno stavljanje izvan snage svih zakona i naredbi iz razdoblja apsolutizma, uključujući i Konkordat. Te je zaključke zatim sankcionirao i kralj. ${ }^{43}$

Sklapanje Konkordata i ranije uzdizanje Zagrebačke biskupije na nadbiskupiju (1852.) odvijalo se u okolnostima koje su za Hrvatsku imale iznimnu

40 Vidi npr. Gesetz vom 25. Mai 1868 wodurch die Vorschriften des zweiten Hauptstückes des allg. Bürgerl. Gesetzbuches über das Eherecht für Katholiken wieder hergestellt, die Gerichtsbarkeit in Ehesachen der Katholiken den weltlichen Gerichtsbehörden überwiesen und Bestimmungen über die bedingte Zulässigkeit der Eheschliessung vor weltlichen Behörden erlassen werden, Reichsgesetzblatt (RGBL) 47/1868.; Gesetz vom 25. Mai 1868, worduch die interconfessionelen Verhältnisse der Staatsbürger in den darin angegeben Beziehungen geregelt werden, $R G B L$ 49/1868.; Gesetz vom 14. Mai 1869, durch welches die Grundsatze des Unterrichtswesens bezüglich der Volksschulen festgestellt werden, $R G B L$ 62/1869.; usporedi Belaj, op. cit. u bilj. 24, str. $61-63$.

41 Zakon od 7. svibnja 1874.: izdaju se u njem ustanove, kojimi se uredjuju izvanjski pravni odnošaji cèrkve katoličke, Dèržavo-zakonski list za kraljevine i zemlje, zastupane u vieću cesarevinskom, god. 1874., komad XVI, br. 50. Papa Benedikt XV. 1921. godine konačno je proglasio prestanak važenja konkordata za Crkvu s obzirom da druga ugovorna strana uslijed političkih razloga više nije postojala. Više vidi u: Doublet, N. J., A Politics of Peace. The Congregation for Extraordinary Ecclesiastical Affairs during the pontificate of Benedict XV (1914-1922), Studium, Roma, 2019.

42 Gross, op. cit. u bilj. 36, str. 335; Adrianyi, G., Die Stellung der ungarischen Kirche zum österreichischen Konkordat vom 1855., Diss. Theol., Roma, 1963.; Torok, P., Hungarian Church - State Relationships: A Socio-Historical Analysis, Doctoral Thesis, University of Toronto, Toronto, 2000., str. 85.

43 Belaj, op. cit. u bilj. 24, str. 63 - 70. Nakon stavljanja Konkordata izvan snage ugarski sudovi i nadalje su priznavali prelatima neograničenu slobodu oporučnog raspolaganja sve do 1871. kada je ministarstvo za bogoštovlje i nastavu ugarske vlade donijelo okružnicu kojom se ističe važenje Kolonićeve konvencije te ograničenje slobode oporučnog raspolaganja prelata. Galić, op. cit. u bilj. 27, str. 997. Ugarsko zakonodavstvo primjenjivalo se na području Međimurja i Baranje. 
političku važnost. ${ }^{44}$ Među hrvatskim svećenstvom nije bilo nezadovoljstva u pogledu sadržaja Konkordata te su se tadašnji najviši dužnosnici Katoličke Crkve, nadbiskup Haulik i biskup Strossmayer, o njemu pozitivno izjašnjavali. No, povratkom ustavnosti i u Hrvatskoj se postavilo pitanje važenja propisa uvedenih u razdoblju apsolutizma. Banska konferencija stoga je usvojila Naputak za privremeno uređenje hrvatskih županija, u kojem je zauzeto stajalište kako do daljnjeg na snazi ostaju svi dotadašnji propisi (1861.). ${ }^{45}$ Jednako je postupio i Hrvatsko-slavonski sabor donijevši odluku o zadržavanju austrijskih zakona uvedenih putem patenata dok ne budu izričito ukinuti ili preinačeni. ${ }^{46}$ Naputak za privremeno uređenje županija, za razliku od saborskih odluka, dobio je kraljevu sankciju te su Konkordat, jednako kao i npr. OGZ, Kazneni zakon ili Građanski parbeni postupnik, odnosno svi tzv. apsolutistički zakoni, i nadalje ostali na snazi, i to kao državni zakoni. U godinama koje su uslijedile, posebice nakon Hrvatsko-ugarske nagodbe (1868.), na temelju koje je Hrvatska imala autonomiju u unutarnjoj upravi, bogoštovlju, nastavi i pravosuđu (§48.), zakonodavnom djelatnošću Sabora neke odredbe Konkordata stavljene su izvan snage. ${ }^{47}$

Na hrvatsko-slavonskom području drugi važan događaj koji je problematizirao valjanost Konkordata bio je prekid državnopravnih veza s Austro-Ugarskom i stvaranje Kraljevine Srba, Hrvata i Slovenaca/Jugoslavije (1918.). ${ }^{48}$ Nadovezujući

$44 \quad$ Vidi Hoško, op. cit. u bilj. 37.

45 Vidi §54. Naputak za privremeno uređenje županija, slobodnih kotareva, slobodnih kraljevskih gradova, povlaštenih trgovišta i seoskih općina u kraljevinah Hrvatskoj, Slavoniji i Dalmaciji, Sbornik zakonah i naredabah valjanih za Kraljevinu Hrvatsku i Slavoniju, godina 1863., komad X., svezak I., str. 277 - 287.

46 O sudbini austrijskih propisa postojala su tri stajališta. Jedni su se zalagali za njihovo zadržavanje bez ikakvih izmjena, drugi su zagovarali povratak prije važećih propisa, dok se treća skupina zalagala za tzv. srednje rješenje, koje je podrazumijevalo prihvaćanje i zadržavanje do daljnjeg austrijskih propisa koji će se preispitati i iz njih zadržati sve ono što "svjetuje politička nužda i djelovita (parcialna) vrsnoća njihova". Vidi uvodni dio u Pravosudne ustanove gradjanskog i kaznenog prava, Saborski spisi sabora kralj. Dalm., Hrv. i Slav. od godine 1861., svezak IV., str. 1; usporedi Maurović, I., Nastojanja i pokušaji, da se reformira opći građanski zakonik, Ljetopis JAZU, sv. 52, 1940., str. $87-88$.

47 Posebno važan bio je zakon kojim je uređeno školstvo za banovanja I. Mažuranića i kojim je ukinuto konkordatsko načelo nadzora crkve nad osnovnoškolskim obrazovanjem. Zakon od 14. listopada 1874. ob ustroju pučkih školah i preparandijah za pučko učiteljstvo u kraljevinah Hrvatskoj i Slavoniji, SZN, god. 1874., kom. XX, br. 49; usporedi i Zakon od 17. siečnja 1906. o vjeroizpovjednim odnosima, SZN, god. 1906., kom. III, br. 8.

48 Na zahtjev podbana, tj. povjerenika za unutrašnje poslove Pokrajinske uprave za Hrvatsku i Slavoniju Milana Rojca o valjanosti Konkordata posebno s obzirom na 
se na prije prihvaćeno stajalište o važenju Konkordata kao državnog zakona, odnosno zakona koji nije uređivao položaj Hrvatske unutar Monarhije, Konkordat je nakon 1918. godine ostao na snazi. ${ }^{49}$ Naime, Kraljevina je bila heterogena država s različitim pravnim, povijesnim, gospodarskim, kulturnim i vjerskim naslijeđem. Različitost pravnog naslijeđa uzrokovala je specifičan pravni ustroj države s postojanjem više različitih pravnih područja. Područja koja su ušla u sastav Kraljevine imala su različita pravna uređenja i izvore prava s obzirom na to da su se prije ujedinjenja nalazila u različitim državnim okvirima. Ti su propisi ostali na snazi i nakon 1. prosinca 1918. ako nisu bili izričito ukinuti.

Nakon 1918. godine za Katoličku Crkvu unutar Kraljevine nastupile su određene promjene pri čemu su veze s Vatikanom održavane preko papinske nuncijature u Beču koja je djelovala kao papinski zastupnik za sva područja bivše Austro-Ugarske. Na III. biskupskoj konferenciji u Zagrebu (1920.) istaknuta je potreba sklapanja konkordata između Kraljevine i Vatikana, dok se u srbijanskim političkim, pravnim i vjerskim krugovima zagovaralo proširenje važenja Konkordata koji su 1914. sklopili Kraljevina Srbija i Vatikan. ${ }^{50}$ Uređenje odnosa jugoslavenske države s Katoličkom Crkvom bilo je osjetljivo pravno pitanje s obzirom na različitost uređenja njezina položaja na pojedinim pravnim područjima, ali i političko pitanje koje je ujedno imalo i znatan vanjskopolitički aspekt jer su neke od biskupija imale svoja sjedišta izvan teritorija Kraljevine, i to u Italiji, Mađarskoj i Austriji. Službeni pregovori Kraljevine i Vatikana počeli su 1925., nakon čega je uslijedio višegodišnji prekid, da bi do potpisivanja Konkordata došlo tek 1935. godine. Unatoč prihvaćanju Konkordata u Narodnoj skupštini (1937.) zbog tzv. konkordatske krize, odnosno nezadovoljstva Srpske Pravoslavne Crkve i srpske političke elite, ali i nezadovoljstva sadržajem Konkordata kod dijela slovenskih i hrvatskih katolika, obustavljen je daljnji zakonodavni postupak. Katolička Crkva bila je jedina vjerska zajednica u Kraljevini koja, za

raspad Monarhije očitovao se i tadašnji prof. kanonskog prava Edo Lovrić u mišljenju podnesenom povjerenstvu za prosvjetu i vjeru u kolovozu 1919. godine. Lovrić, op. cit. u bilj. 37.

49 Uz Konkordat iz 1855. na području Kraljevine primjenjivali su se i konkordati koje su sklopili Kraljevina Crna Gora (1886.) te Kraljevina Srbija (1914.) te Konvencija sklopljena između Svete Stolice i Austro-Ugarske za Bosnu i Hercegovinu (1881.).

50 Troicki, S., Da li važi u Jugoslaviji konkordat sa Srbijom od 1914.?, Arhiv za pravne i društvene nauke, god. 28, drugo kolo za siječanj i veljaču 1938, knjiga 36, br. 1-2, 1938., str. 160 - 164; Wagner, V., Povijest Katoličke crkve u Srbiji u 19. vijeku. (od 1800. do konkordata 1914.), Bogoslovska smotra, vol. 22, br. 2, 1934., str. 124 - 140. 
razliku od ostalih priznatih vjerskih zajednica, nije imala jedinstveno uređen pravni položaj. ${ }^{51}$

\subsection{Konkordat o oporučnom raspolaganju svećenstva}

Primjena postojećih pravila zakonskog i oporučnog nasljeđivanja bila je OGZ-om predviđena do daljnjeg, odnosno do donošenja novih odredbi. Sklapanje Konkordata i njegovo stupanje na snagu unijelo je dvojbe oko pitanja jesu li nastupile promijenjene okolnosti, odnosno jesu li pravila Konkordata utjecala na promjenu pravnog okvira i zakonskog i oporučnog nasljeđivanja.

U Konkordatu su sadržana dva članka - §XIII. i §XXI. - koji uređuju nasljeđivanje svećenstva. §XIII. potvrđena je nadležnost redovnih (svjetovnih) sudova u ostavinskim postupcima iza svećenstva uvedena Izv. p.p. ${ }^{52}$ Sadržaj §XXI. izazvao je određene nejasnoće u pogledu pitanja uređuje li se njime oporučno odnosno zakonsko nasljeđivanje svećenstva. ${ }^{53}$ Unatoč dvojbama, prihvaćeno je stajalište kako ovaj članak ne uređuje zakonsko nasljeđivanje pa su slijedom toga na snazi i dalje ostala prije važeća pravila zakonskog nasljeđivanja. ${ }^{54}$

51 Lanović, M., Konkordat Jugoslavije s Vatikanom, Biblioteka savremenih religiozno-moralnih pitanja, knj. 15. i 16., Beograd, 1925.; Ruspini, I. A., Konkordat Jugoslavije s Vatikanom. Osvrt na istoimenu raspravu dr. M. Lanovića, Bogoslovska smotra, br. 2, 1926., str. 181 - 191; Matijević, Z., Pokušaj razrješenja pravnog položaja Katoličke crkve u Kraljevini SHS 1918. - 1921., Časopis za suvremenu povijest, sv. 17, br. 2, 1985. , str. 51 - 67; Mužić, I., Katolička crkva u Kraljevini Jugoslaviji: politički i pravni aspekti konkordata između Svete Stolice i Kraljevine Jugoslavije, Crkva u svijetu, Split, 1978.

52 "S obzirom na razmjerja sadašnjeg vremena, privoljava Njegova Svetost, da se pravni poslovi duhovnikah, izklopno, svietovni, kao što su pogodbe o pravu vlasničtva, dugovi, baštine, iztražuju i riešavaju po sudovih svietovnih.” (\$XIII.).

53 "U svih krajevih cesarevine bit će arcibiskupom, biskupom i svimkolikim duhovnikom prosto, o onom, što u vrieme smérti svoje ostavili budu nakon sebe, razredjivati po svetih cérkvenih zakonih, kojih ustanove točno obdéržavati imadu i zakoniti baštinici, koji ostavštinu istih nasliede bez naredbe posliednje volje. Nego u jednom i u drugom ovom slučaju bit će kod biskupah, koji biskupijom upravljaju, izuzeta biskupska obilježja i odiela cérkvena, budući da ova smatraju se kao vlastnina térpeze biskupske i prelaze na nasliednika u biskupiji. Ovo isto valja i o knjigah, gdje običaj takov vlada." (\$XXI.).

54 Za prelate je, prema tome, i dalje u primjeni bila Kolonićeva konvencija te se ostavina prelata umrlog bez oporuke morala razdijeliti na tri dijela. Ipak, tijekom ostavinske rasprave nakon smrti zagrebačkog nadbiskupa Josipa Mihalovića na ponovno izražene dvojbe oko primjene pravila zakonskog nasljeđivanja iz Kolonićeve konvencije sudska praksa potvrdila je daljnju primjenu konvencije. To je pitanje bilo raspravljano i među pravnicima koji su o važenju Kolonićeve konvencije imali razli- 
S obzirom na oporučno nasljeđivanje prihvaćeno je stajalište kako su ugarski i hrvatsko-slavonski prelati §XXI. Konkordata stekli neograničenu slobodu oporučnog raspolaganja jer je jedino njima u cijeloj Monarhiji sloboda oporučnog raspolaganja bila do tada ograničena Konvencijom. ${ }^{55}$ Sloboda oporučnog raspolaganja značila je da svećenstvo više nije moralo, u slučajevima kada je htjelo raspolagati cjelokupnom osobnom imovinom, tražiti odobrenje vladara. ${ }^{56}$ Ipak, zajamčena sloboda oporučivanja odnosila se samo na stečenu imovinu te su od raspolaganja bila izuzeta "biskupska obilježja i odiela cèrkvena, budući da ova smatraju se kao vlastnina tèrpeze biskupske i prelaze na nasliednika u biskupiji. Ovo isto valja i o knjigah, gdie običaj takov vlada”. Radi pojašnjenja koja se to imovina isključuje od oporučnog raspolaganja naknadno je izdana naredba kojom je izričito navedena imovina koja ostaje (nad)biskupiji odnosno imovina kojom nije bilo moguće oporučno raspolagati. Tako se nije moglo raspolagati npr. prelatskom mitrom, misnim knjigama ili predmetima koji se koriste pri bogoslužju. ${ }^{57}$ Međutim, moglo se raspolagati predmetima kao što su prstenje ili prsni križevi ako nisu bili pribavljeni crkvenim novcem ili nisu bili poklonjeni crkvi. O tim su predmetima uz naznaku kako su pribavljeni biskupi morali voditi točan zapisnik jer se u protivnom smatralo da su pribavljeni crkvenim novcem. U Ugarskoj, ali i na hrvatsko-slavonskom području, sloboda oporučnog raspolaganja prelata zajamčena Konkordatom bila je povodom brojnih rasprava. ${ }^{58}$

čita stajališta. Vidi raspravu koja se vodila na stranicama Mjesečnika između Luke Marjanovića i Josipa Kuglera: Marjanović, L., Pravo na ostavštinu biskupa bez oporuke umrvšega, Mjesečnik Pravničkog društva, god. XVII, br. 3, 1891., str. 101 - 107; Kugler, I., Opazke na članak: "Pravo na ostavštinu biskupa bez oporuke umrvšega" u br. 3. Mjesečnika 1891., Mjesečnik Pravničkog društva, god. XVII, br. 4, 1891., str. 157 - 166; Marjanović, L., Odgovor na opaske u br. 4. Mjesečnika, Mjesečnik Pravničkog društva, god. XVII, br. 5, 1891., str. 217 - 226; vidi i Rješenje Stola sedmorice od 1. prosinca 1898., br. 2216, u: Galić, op. cit. u bilj. 16, str. 1003 - 1004.

55 Galić, op. cit. u bilj. 27, str. 996.

56 Vranski prior Janko Pavlešić u dva je navrata podnosio molbu vladaru preko Zemaljske vlade (1883. i 1887.) radi dozvole oporučnog raspolaganja cjelokupnom imovinom. Pozivajući se na §XXI. Konkordata Vlada je oba puta odbila zahtjev proslijediti dalje jer odobrenje vladara nije (više) bilo potrebno. Rješenje hrv. slav. dalm. Zemaljske vlade od 26. studenog 1883., br. 13425 i Rješenje hrv. slav. dalm. Zemaljske vlade od 1. studenog 1887., br. 9205, u: Galić, op. cit. u bilj. 27, str. 997.

57 Naredba ministarstvah pravosudja, zatim bogoštovja i nastave od 7. veljače 1859., valjana za svekoliku cesarevinu, u deržavnom listu zakonah kom 7., br. 33. razdan na 16. veljače 1859., kojom se pobliže tumači i ustanovljuje druga točka, saderžana i konkordatu u članku XXI., Pokrajinski list uredovnih spisah za Dalmaciu. Dio pervi, komad X. Razdan i razposlan na 12. ožujka 1859., br. 44, str. 165 - 169.

58 Belaj, op. cit. u bilj. 24, str. 68. 


\section{POSTUPAK KR. FINANCIJALNOG ERARA PROTIV OPORUČNIH NASLJEDNIKA BISKUPA J. J. STROSSMAYERA}

Izloženi pravni okvir bio je na snazi u trenutku smrti biskupa Strossmayera. Tijekom ostavinskog postupka pri osječkom sudu očitovali su se oporučni nasljednici, zatim biskupovi rođaci kao zakonski nasljednici te Financijalni erar koji se također smatrao zakonskim nasljednikom osporavajući pritom valjanost oporuke. Odlukom Stola sedmorice, zbog kolizije nasljednih očitovanja, pozvani su Financijalni erar i srodnici ostavitelja da u roku od 60 dana podnesu tužbu protiv oporučnih nasljednika i ospore valjanost oporuke. ${ }^{59}$ Tužbu je zatim nadležnom Sudbenom stolu u Osijeku podnio Financijalni erar (dalje u tekstu: tužitelj) te je u postupku koji je uslijedio osporavao valjanost oporuke smatrajući kako oporuci nedostaje dozvola vladara za raspolaganje imovinom propisana Konvencijom te da slijedom toga nastupa zakonsko nasljeđivanje. Pritom je tužitelj, kako proizlazi iz spisa, iznio dva stajališta vezana uz valjanost Konkordata. Prema prvom stajalištu Konkordat nije na pravnoj snazi jer je nakon povratka ustavnosti kao neustavan politički zakon ukinut te je ipso facto Konvencija stupila na snagu. To stajalište tužitelj je potkrijepio činjenicom da Konkordat više nije na snazi u Austriji odnosno Ugarskoj. Slijedom tvrdnji o pravnom kontinuitetu zakona iz razdoblja prije uvođenja apsolutizma tužitelj je podnio i različita mišljenja saborskih odbora te prijedloge zakona iz 1861. na temelju kojih bi ti propisi povratkom ustavnosti ipso facto stupili na snagu. ${ }^{60}$ Prema drugom stajalištu, pod pretpostavkom da je Konkordat i dalje na snazi, Konvencija ipak nije ukinuta jer §XXI. Konkordata propisujući uvjete na temelju kojih prelati mogu oporučno raspolagati upućuje na raspolaganje "po svetih crkvenih zakonih" (juxta sacros canones). Takvim se zakonom, prema mišljenju tužitelja, može smatrati upravo Konvencija koja za valjano raspolaganje traži dozvolu vladara. U svojem odgovoru oporučni su nasljednici (dalje u tekstu: tuženici) istaknuli kako je oporuka valjana jer je Konkordatom kao državnim zakonom svim prelatima zajamčena sloboda oporučnog raspolaganja.

Na temelju tužbenog zahtjeva sudovi su razmatrali je li Konkordat na snazi, odnosno je li povratak ustavnosti stavio izvan snage propise uvedene u razdoblju apsolutizma, pa tako i Konkordat, te smatra li se, pod pretpostavkom da je Konkordat i dalje na snazi, Konvencija juxta sacros canones iz §XXI., pa se slijedom toga ne primjenjuje dio Konkordata o oporučnom nasljeđivanju prelata.

$59 \quad$ Vidi bilj. 13.

60 U sudskim spisima ne nalazimo priloge koji sadržavaju mišljenja saborskih odbora i prijedloge zakona. 


\subsection{Je li povratkom ustavnosti 1860. godine na hrvatsko-slavonskom području Konkordat izgubio pravnu snagu?}

Sve tri sudske razine izrazile su stajalište kako je Konkordat na snazi od trenutka uvođenja 1855., pa tako i u vrijeme rješavanja ostavinskog spora nakon smrti biskupa Strossmayera. U prilog tom stajalištu, osporavajući tužbeni zahtjev, Sudbeni stol u Osijeku kao prvostupanjski sud istaknuo je kako je carskim patentom iz 1855. Konkordat proglašen zakonom u skladu s propisanim postupkom proglašenja zakona te je u skladu s §9. OGZ-a na snazi sve dok ga zakonodavac ne izmijeni ili ukine. ${ }^{61}$ Na valjanost Konkordata nije utjecala činjenica da je "proglašen i uveden putem neustavnim", misleći na njegovo uvođenje u neustavnom razdoblju odnosno razdoblju neoapsolutizma. Sud se pritom poziva na Zakon o vlasti sudačkoj (1874.), kojim je izričito isključeno pravo sudova da ispituju ustavnost zakona, odnosno da ispituju je li propis "koji je proglašen valjano" usvojen na ustavni način (\$6.). ${ }^{62}$ Kao treći argument u prilog svojem stajalištu sud navodi Naputak o privremenom uređenju županija, kojim je propisano kako se vlasti imaju obvezu držati postojećih zakona i propisa ako Naputak ne napravi iznimku ili ako novi propisi ne učine neku iznimku (\$54.). ${ }^{63}$ Pozivajući se na ta načela, sud je smatrao kako nije ispravna tvrdnja tužitelja da je povratkom ustavnosti ukinut Konkordat jer promjena ustava i zakonodavne vlasti ne ukida ipso facto postojeće zakone prethodne zakonodavne vlasti. Tome u prilog govori i činjenica da su na snazi ostali i svi ostali zakoni uvedeni u razdoblju neoaposlutizma. Stoga ne stoji ni tvrdnja tužitelja kako je povratkom ustavnosti stupila na snagu Konvencija i slijedom toga odredba na temelju koje je sloboda oporučnog raspolaganja prelata bila vezana uz kraljevo odobrenje.

Tužiteljevu tvrdnju o neprimjeni Konkordata slijedom njegova ukidanja u Austriji i Ugarskoj sud također nije prihvatio. S obzirom na to da Hrvatska nije u neposrednoj državnoj zajednici s Austrijom, ukidanje Konkordata u austrijskom dijelu Monarhije je "posve irelevantno". Također, način ukidanja Konkordata u Ugarskoj nije proveden na način koji bi, prema mišljenju suda, bio relevantan za Hrvatsku. Zaključci Judex-kurijalne konferencije, kojim su ukinuti neoapsolutistički zakoni i privremeno na snagu vraćeno staro ugarsko

${ }^{61} \S 9$. Zakoni imaju dotle svoju moć, dokle ih zakonotvorac ne preinači ili izriekom ne ukine, Rušnov; Posilović, op. cit. u bilj. 2, knjiga I., str. 49.

$62 \S 6$. Sudovom nepristoji sudit o tom, da li je zakon, koji je proglašen valjano, stvoren putem ustavnim; usuprot su sudovi pozvani izpitati valjanost naredabah, ter u tom odlučiti zakonitim putem molbenim. Zakon o vlasti sudačkoj, SZN, god. 1874., kom. VIII, br. 15.

63 Vidi bilj. 45. 
pravo, usvojeni su za Kraljevinu Ugarsku. Naknadno su prihvaćeni u Gornjem i Donjem domu Ugarskog sabora i potvrđeni od strane vladara. Hrvatski predstavnici nisu sudjelovali ni u radu Konferencije ni u radu Sabora, a prihvaćeni zaključci osim toga nisu ni proglašeni u zajedničkom ili hrvatskom službenom listu. Slijedom toga sud smatra kako je Konkordat, ako nije kasnijim zakonima djelomično izmijenjen, i dalje na snazi. Posebno se to odnosi na §XXI. Konkordata, na čiju se (ne)primjenu pozivao tužitelj, a čija je valjanost potvrđena i odlukama Zemaljske vlade. ${ }^{64}$

Rješavajući o prizivu tužitelja unutar Banskog stola pod predsjedanjem Aleksandra pl. Rakodczaya javila su se dva oprečna mišljenja o pravnoj valjanosti oporuke i slijedom toga važenju Konkordata. Sudski izvjestitelj Stevan Dimić te vijećnici Teodor Velendrić, Ignjat Klemenčić, Antun vitez Tajčević i Janko Šibenik prihvatili su obrazloženje Sudbenog stola u Osijeku, dok je vijećnik Krunoslav Klaić iznio suprotno stajalište, s kojim se složio i predsjednik Rakodczay. U prijedlogu izvjestitelja Dimića stoji kako je Konkordat valjano proglašen i stupio na snagu te se primjenjuje dok ne bude izričito ukinut ili izmijenjen. Tužitelj, smatra izvjestitelj, unatoč nastojanju, nije podnio dokaz da je Konkordat stavljen izvan snage i da su slijedom toga na snagu stupili prijašnji propisi. Izvjestitelj navodi i kako se Listopadskom diplomom (dalje u tekstu: Diploma) uređuju državnopravni odnosi u Monarhiji te se njome apsolutistički način vladavine zamjenjuje ustavnim načinom, ne zadirući pritom u zakone i propise kojima se uređuju privatnopravni odnosi. Također, Diplomom nisu ukinuti ni zakoni kojima se uređuju javnopravni odnosi, već, ističe izvjestitelj, navodi se koji će se predmeti uređivati kao dio zajedničke nadležnosti odnosno u okviru autonomne nadležnosti "zemljama spadajućim kr. ugarskoj kruni, u smislu prijašnjih njihovih ustava”. Čak i pod pretpostavkom da je odnos vladara i prelata u pogledu ostavina imao javnopravni karakter, nastavlja izvjestitelj, u skladu s Patentom kojim je uveden OGZ i stupanjem na snagu Konkordata i konkretnih §§. XIII. i XXI., svećeničke ostavine dobile su isključivi privatnopravni karakter. Stoga, prema mišljenju izvjestitelja, Diploma se ne odnosi na §§. XIII. i XXI., čiji sadržaj nije ukinut ni izmijenjen, te je Konkordat i dalje na snazi. Odgovarajući na tvrdnju tužitelja kako zbog prestanka važenja Konkordata na snagu ponovno stupaju prijašnji propisi u pogledu oporučnog raspolaganja prelata, izvjestitelj ističe kako su §XXXV. Konkordata svi prijašnji propis izgubili "moć zakona, koja im pak ne bi bila povraćena već tim, kad bi zaista i prestala bila zakonska moć istog patenta kao zakona, kojim su oni

$64 \quad$ Vidi bilj. 56. 
bili preinačeni ili ukinuti". ${ }^{65}$ Osim toga, izvjestitelj se osvrće i na tužiteljevo osporavanje važenja Naputka o privremenom uređenju županija te ističe kako je Naputak, premda prijelaznog značaja, potvrđen od strane vladara i u svojim odredbama, konkretno u §§ 31. i 54., sadržava opća načela slijedom kojih na snazi ostaju i nadalje svi postojeći zakoni i propisi, i to dok ne budu novim, na temelju ustava donesenim uredbama ukinuti ili preinačeni, neovisno o tome odnose li se na javnopravne ili privatnopravne odnose.

Vijećnik Klaić, s kojim se prilikom glasanja složio i predsjednik suda Rakodczay, smatrao je stajalište tužitelja o nevaljanosti oporuke radi raspolaganja za koje nije prethodno dobiveno odobrenje vladara ispravnim s obzirom na to da je Konvencija i dalje na snazi. Razlažući tijek sklapanja Konvencije i prihvaćanje Zak. čl. 1715.:XVI., koji je "propisno proglašen i inartikuliran i tako stvoren za cjelokupno područje sv. krune Ugarske", Klaić navodi kako Konvencija nije izgubila valjanost prilikom ustroja zagrebačke nadbiskupije jer "tom prigodom nije u nikojem pogledu bud Kolonićeva nagoda, bud zak. čl. XVI. od godine 1715. spomenut". Promjene nisu, prema Klaićevu mišljenju, nastupile ni prilikom uvođenja OGZ-a, kojim su u pogledu oporučne slobode na snazi ostali svi prijašnji propisi. Ni Konkordat nije izričito ukinuo Konvenciju, ali, istodobno ističe Klaić, nigdje se ne spominje ni recepcija Konkordata nakon Diplome jer kod sklapanja tog Konkordata "nije sudjelovao nijedan faktor ug. zakonodavstva - ni krunjeni kralj, ni zakonodavstvo" te je neprekidno na snazi bila Konvencija, odnosno Zak. čl. 1715.:XVI. S obzirom da ni "naše i uže zakonodavstvo" (hrvatsko, op. a.) ne spominje Konkordat, "bio bi zbilja nonsens da nigdje u cijeloj Austro-ugarskoj monarhiji nije više u krijeposti, a samo da bi bio u naših kraljevinah Hrvatskoj i Slavoniji”. U prilog svojem stajalištu Klaić navodi i usvajanje niza zakona - Kaznenog postupka (1875.), tzv. drugog Školskog zakona (1888.) te Zakona o vjeroispovjednim odnosima (1906.) - koji se ne bi mogli uvesti da je na snazi Konkordat ili, primjerice, kako su nadbiskup Haulik te biskupi Kralj i Pavlešić od kralja ishodili dozvole za kodicil i oporuku, a što ne bi bilo potrebno da se primjenjuje Konkordat. ${ }^{66}$ I konačno, Klaić, pozivajući se

65 "Svekolike u cesarevini austrianskoj i u pojedinih pokrajinah, iz kojih je sastavljena, dosada kojim mu drago načinu i u kojem mu drago obliku izdati zakoni, naredbe i odluke, u koliko se sa svečanim ovim ugovorom neslažu, imadu se smatrati kao po njem ukinute; sam pako ugovor imat će od sada za svagda u istih zemljah valjati kao zakon déržavni. Obriču s toga oba ugovornika, da će kako oni tako i nasliednici njihovi sdušno obdéržavati sve i sva koja su ugovorena. Nego ako bi u buduće pojavila se težkoća kakova, porazumiet će se medju sobom Njegova Svetost i Njegovo cesarsko Veličanstvo, za da se stvar prijateljskim načinom razpravi.” (\$XXXV.).

66 Klaić, uz nadbiskupa Jurja Haulika (1788. - 1868.), spominje i biskupe Ivana Kralja (1792. - 1878.) te Janka Pavlešića (1814. - 1893.). Sva trojica bila su poznata po 
na §69. Hrvatsko-ugarske nagodbe, kaže da ako je Konkordat zaista na snazi, onda "bi tako kod nas do veka vriedio, pošto ga ni bez zaključka zajedničkoga ug. hrv. sabora ne bi mogli odkazati, čega isti ni učiniti ne bi htio, čim predleži, da u Ugarskoj nikada pravne valjanosti ni imao nije, pa stoga rečeni sabor ne bi imao ni povoda otkazati". ${ }^{67}$

Navodeći ove argumente Klaić zaključuje kako je biskup Strossmayer umro bez pravno valjane oporuke s obzirom na to da je i dalje na snazi Konvencija, odnosno Zak. čl. 1715.:XVI. te je potrebno prihvatiti zahtjev tužitelja kako mu pripada 1/3 ostavine na temelju zakonskog nasljeđivanja. S Klaićevim mišljenjem složio se i predsjedatelj Rakodczay izjavivši kako Konkordat svakako nije na snazi nakon sklapanja Hrvatsko-ugarske nagodbe, odnosno ulaska Hrvatske i Slavonije u državnu zajednicu s Ugarskom, “jer upitni ugovor u Ugarskoj nije pravno nikad postojao, a u vrieme, u koje je stvoren hrv. zak. čl. I. godine 1868. niti de facto ne". U sudskim spisima nema daljnjih obrazloženja Rakodczayeva stajališta, budućeg bana te budućeg predsjednika Stola sedmorice, u kojemu se mogu nazrijeti i promađarski (politički) stavovi. ${ }^{68}$

Postupak je dovršen na Stolu sedmorice, koji je u povodu izvanrednog previda tužitelja potvrdio presudu Banskog stola obrazlažući kako su niži sudovi ispravno utvrdili kako je §XXI. Konkordata na snazi te kako nije kasnijim propisima izmijenjen te je slijedom toga biskup Strossmayer mogao slobodno raspolagati svojom imovinom bez kraljeva odobrenja.

karitativnom radu te su oporučno ostavili velike iznose različitim zakladama. Jesu li Haulik i Kralj zaista tražili kraljevo odobrenje, nisam uspjela potvrditi, ali Pavlešić jest u dva navrata zatražio dozvolu vladara putem Zemaljske vlade i oba puta je Vlada odbila proslijediti zahtjev vladaru s obzirom da odobrenje na temelju Konkordata više nije bilo potrebno. Vidi bilj. 55. Za Haulika i Kralja usporedi Grlović, M., Album zaslužnih Hrvata XIX. st.: sto i pedeset životopisa, slika i vlastoručnih podpisa: A - L, Zagreb, 1898. - 1900.

$67 \$ 69$. "Nasuprot se i za buduće imadu smatrati zajedničkimi pravi i temeljnimi zakoni Ugarske krune, sva ona ustavna prava, i svi oni temeljni zakoni kojih se užitak i zaštita u prošlosti raznim načinom protezala kako na kraljevinu Ugarsku tako i na kraljevine Hrvatsku i Slavoniju, te koji s nazočnom nagodbom u opreci ne stoje."

68 Zbog opsežnosti rada, ali i namjere da se u radu isključivo prikaže ostavinski postupak i stajališta sudova o primjeni Konkordata s aspekta nasljeđivanja prelata, djelomično je zanemaren nacionalno-politički aspekt problematiziranja valjanosti Konkordata, premda je njegovo zadržavanje u hrvatskom pravnom sustavu imalo, među ostalim, i važnost za obranu hrvatske autonomije. Više vidi u: Strecha, M., "Sve za vjeru i domovinu", idejna strujanja u katolicizmu u Banskoj Hrvatskoj potkraj XIX. stoljeća, Croatica Christiana Periodica, vol. 20, br. 38, 1996., str. 83, 95, 98, 101 i 124. 


\subsection{Je li Kolonićeva konvencija juxta sacros canones?}

U obrazloženju Osječki sud odgovorio je i na tužiteljevu tvrdnju kako je Konvencija juxta sacros canones. Konvencija je, prema mišljenju suda, ugovor između predstavnika Crkve i Dvorske komore, potvrđen naknadno od vladara, koji se na temelju kraljeva naloga trebao primjenjivati pro regula et norma. Iz toga proizlazi kako Konvencija nije crkveni zakon, a ponajmanje "sveti crkveni zakon". Osim toga, ističe sud, prelati su uz kraljevu dozvolu mogli oporučno raspolagati cijelom svojom imovinom, ali ne na temelju Konvencije već na temelju §2. Zak. članka 1715.:XVI. koji je "čisto državni zakon" pa prema tome juxta sacros canones iz §XXI. Konkordata nikako nije Konvencija, ali ni zak. čl. 1715.:XVI. Nastavljajući svoje obrazloženje sud navodi kako uzimajući u obzir §XIII. Konkordata, na temelju kojeg o ostavinama prosuđuju svjetovni sudovi, riječima disponere juxta sacros canones zapravo se savjetuje prelatima uzeti u obzir crkvene zakone, odnosno moralno ih se obvezuje u svojoj oporuci jedan dio ostavine ostaviti ad pias causas, a nikako ih se ne obvezuje postupati u skladu s crkvenim zakonima. U konkretnom slučaju biskup Strossmayer cijelu je svoju imovinu ostavio ad pias causas te je na taj način udovoljio i toj moralnoj obvezi sadržanoj u Konkordatu.

Rješavajući o prizivu na Banskom stolu izvjestitelj, pozivajući se na §XXXV. Konkordata kojim je Konvencija stavljena izvan snage, drži kako nije moguće istu smatrati "svetim kanonom" jer se takvim ne smatraju, ponavljajući riječi tužitelja, ni pravila sadržana u Corpus iuris canonici. Stoga potvrđuje odluku nižeg suda kako se riječi juxta sacros canones odnose na pro foro interno, odnosno na moralnu obvezu ostavitelja u svojoj oporuci ostaviti dio imovine ad pias causas. Za razliku od izvjestitelja, vijećnik Klaić u svojem se mišljenju nije osvrnuo na tužiteljevu tvrdnju o Konvenciji kao juxta sacros canones.

Rješavajući o izvanrednom previdu tužitelja Stol sedmorice je, potvrdivši presudu Banskog stola, istaknuo kako se ni Konvencija ni Zak. čl. 1715.:XVI. ne mogu smatrati juxta sacros canones.

\section{ZAKLJUČAK}

Povratkom ustavnosti u Hrvatskoj se, uz uređenje odnosa prema Ugarskoj i izgradnji institucija autonomne vlasti, raspravljalo i o daljnjoj primjeni austrijskih propisa čije je važenje carskim patentima protegnuto na hrvatsko-slavonsko područje tijekom apsolutizma. Stajalište Banske konferencije, koja je uredila prijelaz države iz razdoblja apsolutizma u ustavno stanje, kako na snazi ostaju svi do tada važeći zakon, prihvaćeno je i na zasjedanju Hrvatsko-slavonskog 
sabora 1861. donošenjem zaključka na temelju kojeg svi austrijski propisi ostaju na snazi dok ne budu izričito ukinuti ili zamijenjeni odgovarajućim hrvatskim propisima. Slijedom tih odluka na snazi je ostao i austrijski Konkordat i OGZ te niz drugih zakona. Nesumnjivo je da su zakonodavnom djelatnošću Sabora (npr. uređenje školstva ili uređenje međuvjerskih odnosa) u godinama koje su uslijedile, posebice nakon Hrvatsko-ugarske nagodbe (1868.), neke odredbe Konkordata stavljene izvan snage. Međutim, za razliku od Austrije i Ugarske, Konkordat nije u cijelosti ni izričito stavljen izvan snage te se nastavio primjenjivati, iako se njegova valjanost povremeno dovodila u pitanje.

Oporučno raspolaganje biskupa Strossmayera potaknulo je ponovnu raspravu o valjanosti Konkordata, pri čemu se pred hrvatskim sudovima o Konkordatu raspravljalo u kontekstu njime zajamčene slobode oporučnog raspolaganja prelata. Na temelju tužbenog zahtjeva u povodu osporavanja oporuke sudovi su razmatrali je li Konkordat na snazi, odnosno je li povratak ustavnosti stavio izvan snage propise uvedene u razdoblju apsolutizma, pa tako i Konkordat, te smatra li se, pod pretpostavkom da je Konkordat i dalje na snazi, Kolonićeva konvencija juxta sacros canones, na koju se poziva §XXI. Konkordata, pa se slijedom toga ne primjenjuje njegov dio o oporučnoj slobodi raspolaganja prelata već je za valjano mortis causa raspolaganje potrebno odobrenje vladara. Kako biskup Strossmayer, prema mišljenju tužitelja, nije imao odobrenje vladara, njegova oporuka nije valjana te se primjenjuju pravila zakonskog nasljeđivanja koja tužitelja smatraju jednim od nasljednika s pravom na $1 / 3$ ostavine.

Sve tri sudske razine (Sudbeni stol, Banski stol, Stol sedmorice) bile su stajališta kako je Konkordat i dalje na snazi, Kolonićeva konvencija nije juxta sacros canones te je oporučno raspolaganje biskupa Strossmayera valjano. U zauzimanju tog stajališta prvostupanjski Sudbeni stol je istaknuo, što je prihvaćeno od Banskog stola i Stola sedmorice, kako je Konkordat proglašen u skladu za zakonom te je pritom nevažno što je do njegova proglašenja došlo tijekom apsolutizma jer prema Zakonu o vlasti sudačkoj sudovi ne mogu ocjenjivati ustavnost zakona koji je proglašen valjano. Osim toga, Naputak o privremenom uređenju županija potvrđen od strane vladara propisao je primjenu svih neoapsolutističkih propisa do izričitog ukidanja ili zamjene odgovarajućim hrvatskim propisima, dok činjenica da su Austrija i Ugarska ukinule Konkordat nije bila od nikakvog utjecaja za Hrvatsku. Pri Banskom stolu posebno je istaknuto kako Listopadska diploma, kojom je ukinut apsolutizam, nije zadirala u zakone i propise kojima se uređuju privatnopravni odnosi, ostavinski predmeti to svakako jesu, ali ni u zakone i propise javnopravnog karaktera. Drugo, suprotno (i neprihvaćeno) mišljenje unutar Banskog stola zagovaralo je nevaljanost Konkordata, temeljeći to stajalište na činjenici da pri njegovu sklapanju nije sudjelovao ni jedan (ugarski) zakonodavni čimbenik te je stoga na snazi i dalje Kolonićeva konvencija. I Stol 
sedmorice zauzeo je stajalište kako je oporučno raspolaganje biskupa valjano, odnosno da je Konkordat i dalje na snazi. Osim što je Konkordat smatran državnim zakonom te se primjenjivao kao državni zakon, sudska su tijela vlasti držala i da je Kolonićeva konvencija, čije je važenje potvrđeno zak. čl. 1715:XVI, bila državni zakon, a nikako ne juxta sacros canones, tj. sveti crkveni zakon, kakvom bi kvalifikacijom bila omogućena njezina primjena pozivanjem na Konkordat.

Prema tome, sve tri sudske razine smatrale su Konkordat državnim zakonom kojemu se “...mora (...) još i danas priznati pravna snaga, jer on izmedju valjano proglašenih zakona ne može iznimku činiti”. ${ }^{69}$

\section{IZVORI I LITERATURA}

\section{Neobjavljeni izvori:}

Hrvatski državni arhiv, fond 394, Stol sedmorice (1862. - 1945.), serija ostavina, kutija 3., Os-IV-421/1905.

\section{Objavljeni izvori:}

Cesarski patent od 5. studenog 1855, kriepostan za svekoliku cesarevinu kojim se proglašuje ugovor (konkordat), Pokrajinski list uredovnih spisah za Dalmaciu. Dio pervi, komad XXXIII. Razdan i razposlan na 6. prosinca 1855., br. 209,

Cesarski patent od 9. kolovoza 1854 krjepostan za svekolike krunovine, izim Krajine vojničke, Hrvatski zakoni III, Knjižara Lav. Hartmana (Kugli i Deutsch), Zagreb, 1900.

Gesetz vom 25. Mai 1868 wodurch die Vorschriften des zweiten Hauptstückes des allg. Bürgerl. Gesetzbuches über das Eherecht für Katholiken wieder hergestellt, die Gerichtsbarkeit in Ehesachen der Katholiken den weltlichen Gerichtsbehörden überwiesen und Bestimmungen über die bedingte Zulässigkeit der Eheschliessung vor weltlichen Behörden erlassen werden, Reichsgesetzblatt (RGBL) 47/1868.

Gesetz vom 25. Mai 1868, wodurch die interconfessionelen Verhältnisse der Staatsbürger in den darin angegeben Beziehungen geregelt werden, $R G B L$ 49/1868.; Gesetz vom 14. Mai 1869, durch welches die Grundsatze des Unterrichtswesens bezüglich der Volksschulen festgestellt werden, $R G B L$ 62/1869.

69 Iz presude Sudbenog stola u Osijeku, br. 2101, str. 9, HDA, Stol sedmorice, kut. 3. 
Naputak za privremeno uređenje županija, slobodnih kotareva, slobodnih kraljevskih gradova, povlaštenih trgovišta i seoskih općina u kraljevinah Hrvatskoj, Slavoniji i Dalmaciji, Sbornik zakonah i naredabah valjanih za Kraljevinu Hrvatsku i Slavoniju (SZN), godina 1863., komad X., svezak I.

Naredba hrv. slav. dalm. zemaljske vlade, odjela za bogoštovlje i nastavu te odjela za pravosudje, od 21. listopada 1918. br. 20.673, o postupku povodom smrti katoličkih biskupa (zagrebačkog nadbiskupa metropolite i sufraganih mu biskupa), uživaoca nadarbina kraljeva imenovanja; Naredba hrv. slav. dalm. zemaljske vlade, odjela za bogoštovlje i nastavu, od 21. listopada 1918. broj 30.779, o upravi, nadzoru i predaji nadarbine zagrebačkog nadbiskupa - metropolite, kao što i nadarbine sufraganih mu biskupa kraljeva imenovanja, Zbornik zakona i naredaba valjanih za Hrvatsku i Slavoniju, god. 1918., kom. XV, br. 97. i br. 98 .

Naredba ministarstvah pravosudja, zatim bogoštovja i nastave od 7 . veljače 1859., valjana za svekoliku cesarevinu, u deržavnom listu zakonah kom 7., br. 33. razdan na 16. veljače 1859., kojom se pobliže tumači i ustanovljuje druga točka, saderžana i konkordatu u članku XXI., Pokrajinski list uredovnih spisah za Dalmaciu. Dio pervi, komad X. Razdan i razposlan na 12. ožujka 1859., br. 44.

Okružnica kralj. banskog stola od 31. svibnja 1876. br. 5677., glede pitanja komu pripadaju ošastne ostavštine. Okružnica kr. banskog stola od 29. studenoga 1882. br. 23530., kojom se okružnica kr. banskoga stola od 31. svibnja 1876. br. 5677 proteže i na područje bivše hrvatsko-slavonske krajine. Uredovna sbirka naredabah pravosudne struke, svezak I, Zagreb, 1885., br. 31.

Pravosudne ustanove gradjanskog i kaznenog prava, Saborski spisi sabora kralj. Dalm., Hrv. i Slav. od godine 1861., svezak IV.

Rješenje kr. Banskog stola od 6. srpnja 1893. br. 12239, Mjesečnik Pravničkog društva, god. XX, br. 11, 1894., str. 502. - 503.

Rješenje kr. stola sedmorice od 24. lipnja 1896. br. 14718, Mjesečnik Pravničkog društva, god. XXII, 1896., str. 552.

Zakon o sudbenom postupku u pravnim poslovima neparbenim iliti izvan parnica od 9. kolovoza 1854., Hrvatski zakoni III, Knjižara Lav. Hartmana (Kugli i Deutsch), Zagreb, 1900.

Zakon o sudskom vanparničnom postupku, Službene novine Kraljevine Jugoslavije od 1. augusta 1934., br. 175 - XLV.

Zakon o vlasti sudačkoj, SZN, god. 1874., kom. VIII, br. 15.

Zakon od 14. listopada 1874. ob ustroju pučkih školah i preparandijah za pučko učiteljstvo u kraljevinah Hrvatskoj i Slavoniji, SZN, god. 1874., kom. XX, br. 49. 
Zakon od 17. siečnja 1906. o vjeroizpovjednim odnosima, SZN, god. 1906., kom. III, br. 8 .

Zakon od 7. svibnja 1874: izdaju se u njem ustanove, kojimi se uredjuju izvanjski pravni odnošaji cèrkve katoličke, Dèržavo-zakonski list za kraljevine i zemlje, zastupane u vieću cesarevinskom, god. 1874., komad XVI, br. 50.

\section{Literatura:}

Adrianyi, G., Die Stellung der ungarischen Kirche zum österreichischen Konkordat vom 1855., Diss. Theol., Roma, 1963.

Aliprantis, C., The afterlife of Enlightened Absolutism: commemoration of Maria Theresa and Joseph II and the politics of liberal reform in nineteenth-century imperial Austria, European Review of History, vol. 26, br. 2, 2019., str. 305 - 330.

Belaj, F., Katoličko crkveno pravo, Tisak i naklada knjižare L. Hartmana (Stj. Kugli), Zagreb, 1901.

Beuc, I., Povijest institucija državne vlasti Kraljevine Hrvatske, Slavonije i Dalmacije, Pravni fakultet - Centar za stručno usavršavanje i suradnju s udruženim radom, Zagreb, 1985.

Doublet, N. J., A Politics of Peace. The Congregation for Extraordinary Ecclesiastical Affairs during the pontificate of Benedict XV (1914-1922), Studium, Roma, 2019.

Galić, I., O oporučnoj sposobnosti i zakonskom nasljedovanju iza katoličkih duhovnih osoba, Mjesečnik Pravničkog društva u Zagrebu, god. XXXVI, br. 11, 1910., str. 973 - 1011 .

Galić, I., O postupku nakon smrti katoličkih prelata, o preuzeću i upravi ispražnjenih prelatskih nadarbina, o diobi dohodaka nadarbine i godini prelatove smrti te o predaji nadarbine novo imenovanom prelatu, Mjesečnik Pravničkog društva u Zagrebu, god. XXXVIII, 1912., knjiga I, br. 1, str. 1-9.; br. 2, str. 113 - 125.; br. 3, str. $199-208$.

Grlović, M., Album zaslužnih Hrvata XIX. st.: sto i pedeset životopisa, slika i vlastoručnih podpisa: A - L, Zagreb, 1898. - 1900.

Gross, K., Udžbenik crkvenog prava Katoličke crkve, Naklada školskih knjiga i tiskanica kr. Banske uprave Savske banovine, Zagreb, 1930.

Gross, M., Počeci moderne Hrvatske, Globus, Zagreb, 1986.

Hoško, F. E., Promaknuće Zagrebačke biskupije u nadbiskupiju omogućila je revolucionarna 1848. godina, Riječki teološki časopis, god. 26, br. 1, 2018., str. 131 - 164.

Krešić, M., Much Ado about Nothing - Debates on the Type of Marriage in Yugoslavia between the Two World Wars, u: Löhnig M. (ur.), Kulturkampf um die Ehe, Reform 
das europäischen Eherechts nach dem Grossen Krieg, Mohr Siebeck, Tübingen, 2021., str. $187-222$.

Kugler, I., Opazke na članak: „Pravo na ostavštinu biskupa bez oporuke umrvšega“ u br. 3. Mjesečnika 1891., Mjesečnik Pravničkog društva, god. XVII, br. 4, 1891., str. $157-166$.

Lanović, M., Konkordat Jugoslavije s Vatikanom, Biblioteka savremenih religiozno-moralnih pitanja, knj. 15. i 16., Beograd, 1925.

Lanović, M., Privatno pravo Tripartita, Tipografija D.D., Zagreb, 1929.

Lovrić, E., Vrijednost konkordata u Hrvatskoj prije i nakon sloma Austro-Ugarske, Mjesečnik Pravničkog društva, god. XLVIII, br. 4 - 5, 1921., str. 197 - 216.

Marjanović, L., Odgovor na opaske u br. 4. Mjesečnika., Mjesečnik Pravničkog društva, god. XVII, br. 5, 1891., str. 217 - 226.

Marjanović, L., Pravo na ostavštinu biskupa bez oporuke umrvšega, Mjesečnik Pravničkog društva, god. XVII, br. 3, 1891., str. 101 - 107.

Matijević, Z., Pokušaj razrješenja pravnog položaja Katoličke crkve u Kraljevini SHS 1918. - 1921., Časopis za suvremenu povijest, vol. 17, br. 2, 1985., str. 51 - 67.

Maurović, I., Nastojanja i pokušaji, da se reformira opći građanski zakonik, Ljetopis JAZU-u, sv. 52, 1940., str. $84-97$.

Mužić, I., Katolička crkva u Kraljevini Jugoslaviji: politički i pravni aspekti konkordata izmedu Svete Stolice i Kraljevine Jugoslavije, Crkva u svijetu, Split, 1978.

Nánásy, B., Testamentom a’ magyar országi törvények szerént, Trattner Mátjás betűjvel, Pesthen, 1798., str. $52-65$.

Ruspini, I. A., Konkordat Jugoslavije s Vatikanom. Osvrt na istoimenu raspravu dr. M. Lanovića, Bogoslovska smotra, sv. 2, 1926., str. 181 - 191.

Rušnov, A.; Posilović, S., Tumač obćemu austrijskom gradjanskom zakoniku, knjiga I. i knjiga II., Tisak i naklada knjižare L. Hartmana (Stj. Kugli), Zagreb, [1910].

Sedlák, P., Leopold Kollonić (1631.-1707.) - kardinal hrvatskog podrijetla i njegova crkvena $i$ politička djelatnost (300. obljetnica smrti primasa Leopolda Kollonića), Croatica Christiana periodica, vol. 31, br. 60, 2007., str. 85 - 99.

Sršan, S. (prir.), Ostavština đakovačkog i srijemskog biskupa Josipa Jurja Strossmayera 1905. godine: zapisnici ostavinskog povjerenstva i spisi ostavinske rasprave, Zagreb - Osijek: Hrvatska akademija znanosti i umjetnosti, Zavod za znanstveni i umjetnički rad: Državni arhiv Đakovo; Đakovačka i srijemska biskupija, 2006.

Strecha, M., „Sve za vjeru i domovinu“, idejna strujanja u katolicizmu u Banskoj Hrvatskoj potkraj XIX. stoljeća, Croatica Christiana Periodica, vol. 20, br. 38, 1996., str. $72-132$. 
Torok, P., Hungarian Church - State Relationships: A Socio - Historical Analysis, Doctoral Thesis, University of Toronto, Toronto, 2000.

Troicki, S., Da li važi u Jugoslaviji konkordat sa Srbijom od 1914.?, Arhiv za pravne i društvene nauke, god. 28, drugo kolo za siječanj i veljaču 1938, knjiga 36, br. 1-2, 1938., str. $160-164$.

Wagner, V., Povijest Katoličke crkve u Srbiji u 19. vijeku. (od 1800. do konkordata 1914.), Bogoslovska smotra, vol. 22, br. 2, 1934., str. 124 - 140. 
Summary

\section{Mirela Krešić}

\section{“THE CONCORDAT'S LEGAL FORCE MUST BE RECOGNISED STILL TODAY, SINCE THERE CAN BE NO EXCEPTION AMONG VALIDLY PROMULGATED ACTS"}

After the abolishment of neo-absolutism and the restoration of constitutionality (1860), there were debates on the validity of Austrian regulations introduced by means of patents, including the 1855 Concordat. There were often opposing views on the issue, therefore it was discussed not only from a legal standpoint but also as a significant national-political and ecclesiastical issue.

Using probate records from the holdings of the Table of Seven (Stol sedmorice) kept in the Croatian State Archives pertaining to a claim of the title of inheritance after Bishop Strossmayer's death, the paper reconstructs a legal framework for regulating the title of inheritance on the basis of the prelate's will and analyses judgements of the Royal Court Table in Osijek (Kraljevski sudbeni stol), the Ban's Court (Banski stol) and the Table of Seven and their reasonings.

Based on the claim arising from the challenge of the bishop's will, the courts of law deliberated the validity of the Concordat and considered the issue of whether restoration of constitutionality repealed the regulations that had been introduced during the period of absolutism, including the Concordat. Assuming that the Concordat was still in force, the courts examined the issue of whether Kolonic's (Kollonich, Kollonitsch) Convention was considered a piece of legislation that had been in force earlier, i.e. juxta sacros canones invoked by $\$ X X I$ of the Concordat, not allowing the application of the part referring to the prelate's freedom to dispose by will. Instead, the valid dispositions by will required the ruler's approval. Since in the view of the plaintiff, Bishop Strossmayer had not obtained the ruler's approval, his will was null and void. Consequently, rules of intestacy applied according to which the plaintiff was one of the heirs entitled to one third of the assets.

All three judicial levels held that the Concordat as a State law continued to be in force, that Kolonic's Convention was not juxta sacros canones, and that Bishop Strossmayer's testamentary disposition was valid. In their finding, the courts emphasised that the Concordat had been promulgated in accordance with the law. They deemed the fact that the Concordat had been promulgated during absolutism to be of no consequence since, in accordance with the Law on Judiciary (Zakon o vlasti sudačkoj), courts of law could

Mirela Krešić, Ph. D., Associate Professor, Faculty of Law, University of Zagreb, Trg Republike Hrvatske 14, 10000 Zagreb, Croatia; mirela.kresic@pravo.hr;

ORCID ID: ocid.org/0000-0001-7065-7129 
not assess the constitutionality of pieces of legislation that had been duly promulgated. Moreover, the Instruction on the Provisional Regulation of Counties (Naputak o privremenom uređenju županija) provided for the application of all neo-absolutist regulations until their explicit repeal or replacement by appropriate Croatian regulations, whereas the fact that Austria and Hungary had repealed the Concordat had no impact whatsoever on Croatia. The judicial bodies held that the Concordat was a State law and applicable as such. In addition, they also held that Kolonićs Convention, whose validity was confirmed by legislative Article 1715:XVI, was a State law, and by no means juxta sacros canones, i.e. the holy law of the Church, which was the qualification that would have enabled its application by invoking the Concordat.

Keywords: the 1855 Concordat; General Civil Code; Croatia and Slavonia; Josip Juraj Strossmayer, will 